\title{
Leitura
}

\section{Refletindo sobre supervisão}

\section{Henrlette Tognettl Penha Morato}

Rogério C. Buys me fez parar e pensar. Afinal, desde nossa formação, como estudantes de Psicologia, nos é enfatizada e requerida a vivência de supervisão (é parte integrante do currículo nos estágios das disciplinas profissionalizantes); mesmo depois, já psicólogos, continuamos sentindo a necessidade de, em alguns momentos dificeis e confusos de nossa atividade profissional, procurarmos a ajuda de supervisores. "Sabemos", portanto, sobre a importância do papel da supervisão, mas raramente nos detemos para refletir sobre o seu significado quer em nossa formaçāo, quer em nossa prática profissional. Somos supervisionados, somos supervisores e pouco nos damos conta do sentido da supervisāo e sua sistemática para o psicólogo.

E é a isso que Rogério, através de seu livro "Supervisāo de Psicoterapia na Abordagem Humanista Centrada na Pessoa" (Summus Editorial, 111p.) nos leva - uma reflexão sobre o espaço fundamental da supervisão, levantando uma proposta para a sua sistematização (Capitulo 1). Ainda que enfocado, especificamente, a supervisāo de psicoterapia (é na prática clínica onde, talvez, mais reverbere a relevância desse espaço para o terapeuta), e baseando-se numa aborgagem determinada (Abordagem Centrada na Pessoa), Rogério procura transmitir o quanto "a supervisão é uma atividade específica na vida pro- fissional do psicólogo que não pode nem substituir nem ser substituída por nenhuma outra" (p.18), já que se constitui num espaço fundamental para a reflexão das relaçōes profissionais vividas.

Valendo-se de sua experiência como professor, supervisor e psicoterapeuta, ele procura dar subsídios a que se repense o triplo vértice da atividade do terapeuta: o teórico, o técnico e o experiencial, o que nos dirige para a supervisão como o espaço integrador desses três fatores para o aprimoramento da prática clínica. Suas colocaçōes possibilitam generalizaçōes refe. rentes a supervisões de outras atividades do psicólogo, remetendo-nos, dessa forma, ao questionamento sobre o credenciamento de supervisores junto aos Conselhos Regionais. Seria suficiente ter-se, apenas, uma experiência clínica de alguns anos para poder ser supervisor? Ou, como Rogério sugere, supervisão envolve também uma técnica que necessita estar amparada também em uma teoria, além da prática, sendo, portanto, uma situaçào claramente delimitada, com um objetivo específico e requerendo um profundo comprometimento do supervisor?

Partindo desse posicionamento, Rogério propōe-se a sistematizar uma técnica de supervisāo compreendendo as funções didática (teórico-técnica) e experiencial. Na primeira, haveria o compromisso de tratar-se a supervisão como a parte de ligação entre o que é enfatizado, generalizadamente, por uma teoria como sendo a compreensão dos processos psicológicos e o que é a particularidade desses mesmos processos no cliente em foco (teórica), bem como é enfocada a maneira de se trabalhar com o cliente (técnico), sem grandes intelectualizaçōes, mas sim facilitando a conscientização do elo entre a teoria, a técnica e a realidade psicológica. Por sua vez, a função experiencial da supervisào possibilitaria a facilitação das experienciaçōes do supervisonando na sua relaçāo com seu cliente: suas percepções e comunicaçōes, enfim, seus sentimentos e atitudes no processo terapêutico, segundo as condições básicas da Abordagem Centrada na Pessoa.

A partir daí, Rogério sugere dois modelos de supervisão: o transitivo (mais voltado para uma avaliação, por parte do supervisor, do desempenho do supervisionando nos seus atendimentos; visando sua aprendiza. gem escrita), e o intransitivo (onde o supervisor dispōe-se a facilitar ao supervisionando uma aprendizagem ampla de seu próprio jeito de ser terapeuta).

Ainda que orientado para a Abordagem Centrada na Pessoa, o livro de Rogério também possibilita àqueles que confundem essa Abordagem com as idéias de Carl Rogers uma oportunidade de entrar em contato com o pensamento de outros autores, como Gendlin, que procuram reformular e fundamentar as concepçōes rogerianas, ampliando, dessa forma, sua compreensão.

Para mim, ressaltam-se dois méritos no trabalho de Rogério. Por um lado, seu pioneirismo, em termos de uma experiência de nossa realidade, de propor, com seu livro, uma abertura essencial para que professores de Psicologia e supervisores possam iniciar uma reflexảo mais criteriosa sobre a atividade de supervisão, visando a um aprimoramento de formaçāo dos psicólogos de que tanto necessitamos. Por outro lado, sua ousadia de, baseado em suas próprias experiências e questionamentos, porpor-se uma tentariva de sistematizar seu rrabalho com supervisão, e, mais ainda, de comunicá-la publicamente, propiciando, dessa forma, o preenchimento dessa curiosa lacuna bibliográfica sobre supervisão. 


\section{Leitura}

Como tratar o medo de
dentista?

Inúbla Duarte*

$\mathrm{O}$ "medo do dentista", que tantos prejuízos pode trazer à saúde das pessoas, nas mais diversas idades, pode agora ser mais bem compreendido. A possibilidade de "aplicar a Psicologia na prática/odontológica" foi a feliz associação realizada pela psicóloga e odontóloga Prof'. Myrna Cicely Couto Giron, em seu livro "Fundamentos Psicológicos da Prática Odontológica" (D. C. Luzzato Editores Ltda, P. Alegre, 1988).

Em sua obra, a autora, com linguagem clara e de fácil compreensão, consegue ir desenvolvendo conceitos psicológicos fundamentais à compreensão da dinâmica da personalidade, aliando-os a sua rica vivência como odontóloga e professora de Psicologia Aplicada, no curso de Odontologia. Leva o leitor à estreita interrelaçāo do indivíduo com o "meio" $e$. mais especificamente, à relação com a figura "temida" daquele que é responsável pela prevençào e tratamento de nossos dentes - o dentista.

Realidade e fantasia são estudadas, observadas e entendidas na complexidade das relações odontólogo-paciente e em consonância com suas experiências existenciais.

Com esta obra, a autora procura capacitar o futuro odontólogo para um melhor e mais adequado desempenho profissional, através da compreensão dos aspectos psicológicos envolvidos em sua situação de trabalho; com o objetivo de libertá-lo da pressāo em ser onipotente, de resolver dificuldades que escapam aos limites odontológicos, sāo expostos aspectos importantes que caracterizam o ser humano, nos seus mais diferentes momentos vitais, com a preocupação de diferenciar entre reaçōes ditas "normais" de outras consideradas "patológicas".

Com rara capacidade de síntese e integraçāo, a autora torna possivel o conhecimento do funcionamento da pessoa, desde seu nascimento até a velhice, sob o enfoque psicanalítico. As crises vitais, com suas características específicas; a ansiedade, suas manifestações e as defesas utilizadas na situação de conflito, sào entendidas através de contribuiçōes advindas de Freud, Melanie Klein, Anna Freud, Erick Erickson, Arminda Aberastury e Lidz, entre outros.

A compreensão dos fatores ansiogênicos despertados nas situações de dor, de enfermidades e de cirurgias na prática odontológica é necessária e fundamental para que exista uma geral conscientização de que o "odontólogo nāo trata apenas de uma boca e

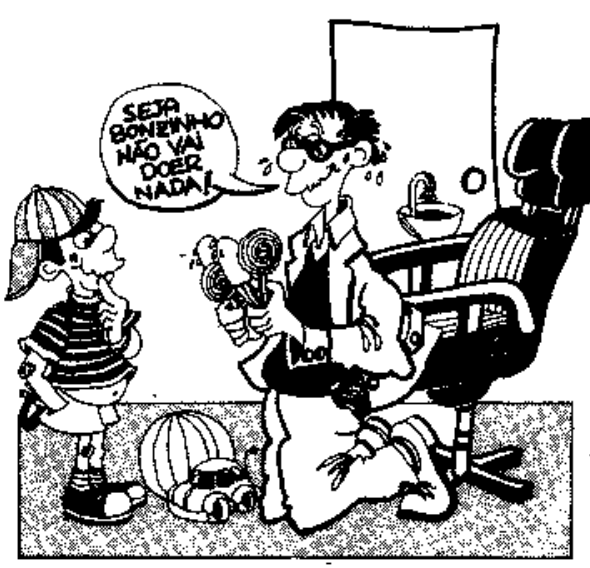

sim de uma boca que faz parte de uma pessoa", com hisrória - passado, presente e futuro - inserida na complexidade do contexto sócio-econô. mico-cultural em que vive.

Os estereótipos atribuídos ao odontólogo, em consequêencia de aspectos inconscientes originados da ansiedade de castração, sentimentos de culpa etc. revelados através de simbolismos de dentes e do processo de dentição, chamam nossa atenção para a dificil tarefa que esse profissional de saúde enfrenta no seu dia-a-dia. $O$ cirurgião-dentista é identificado, em brincadeiras, em charges de jornais e revistas, como o "agressor, o carrasco", fazendo com que surjam atitudes punitivas na dinâmica "vítima-agressor" - sociedade - paciente odontólogo.

Mas talvez a questão mais relevante nesta obra, seja o alerta que a autora faz quanto às ansiedades patológicas frente ao tratamento dentário, que levam crianças, adolescentes, adultos e velhos, não só a abandonarem os tratamentos necessários, como às enfermidades intercorrentes, à negação completa da existência de dentes, que impedem o paciente de ir ao dentista. As possíveis intervençōes que este pode realizar $\mathrm{c}$ a necessidade da ajuda de um psicólogo na solução de problemas emocionais mais severos são enfatizadas através do relato da experiência da autora, nesta obra que é o resultado de uma feliz união de duas áreas - a da Odontologia e a da Psicologia.

* Mestre em Psicologia Aplicada. Profó no lnstituto de Psicologia da PLCRS, nas disciplinas de Ética Profissional e Psicologia Clínica. Coordenadora e Supervisora da Sociedade Núcleo de Estudos em Psicoterapia NEP. P. Alegre - RS. 